\title{
Can nesting waterbirds influence the community structure of macroinvertebrates in southern Brazilian intermittent wetlands?
}

\author{
Daniela C. Zardo (D), Marcela M. Souza (1D, Mateus M. Pires (D), \\ Cristina Stenert (1) \& Leonardo Maltchik (1)
}

Laboratory of Ecology and Conservation of Aquatic Ecosystems, Universidade do Vale do Riio dos Sinos, Av. Unisinos, 950, $93022-750$ São Leopoldo, RS, Brazil. (danielazardo51@hotmail.com; mmarmitts.tk@gmail.com; marquespiresm@gmail.com; cstenert@unisinos.br; maltchik@unisinos.br)

\author{
Received 18 May 2019 \\ Accepted 01 June 2020 \\ Published 10 August 2020 \\ DOI 10.1590/1678-4766e2020015
}

\begin{abstract}
The main goal of this study was to test the effect of the presence of nesting waterbirds on the taxonomic structure (richness, abundance and composition) of macroinvertebrate communities in southern Brazilian wetlands. Macroinvertebrate communities were seasonally sampled in eight intermittent wetlands differing according to the occurrence of nesting colonies of waterbirds (four with the presence of rookeries; four without). The influence of nutrients and water and sediment physicochemical variables on macroinvertebrate communities was also assessed. The community structure of aquatic macroinvertebrates was not affected by the presence of colonies of nesting waterbirds. Rather, macroinvertebrate communities varied seasonally and they were influenced by water-level environmental variables. Richness and composition changed among seasons and were influenced by nutrients and water physicochemical variables. Water turbidity and total dissolved solids influenced macroinvertebrate richness, while water nutrients affected macroinvertebrate abundance. Our results indicate that the lack of effect of nesting waterbirds on macroinvertebrates is possibly due to the variation in the composition of avian species and their reduced population sizes, and in such cases, any effects of birds on macroinvertebrates can be overridden by water chemistry and seasonal changes in intermittent wetlands.
\end{abstract}

KEYWORDS. Aquatic invertebrates, ponds, waterfowl, water chemistry.

RESUMO. Podem as colônias de nidificação de aves aquáticas influenciar a estrutura da comunidade de macroinvertebrados em áreas úmidas intermitentes do sul do Brasil? O principal objetivo deste estudo foi testar o efeito da presença de colônias de nidificação de aves aquáticas sobre a estrutura taxonômica (riqueza, abundância e composição) de comunidades de macroinvertebrados em áreas úmidas do sul do Brasil. As comunidades de macroinvertebrados foram amostradas sazonalmente em oito áreas úmidas intermitentes, diferindo de acordo com a ocorrência de colônias de nidificação de aves aquáticas (quatro áreas úmidas com e quatro áreas úmidas sem a presença de ninhais). A influência de nutrientes e das variáveis físico-químicas da água e do sedimento nas comunidades de macroinvertebrados também foi avaliada. A estrutura da comunidade de macroinvertebrados aquáticos não foi afetada pela ocorrência de colônias de nidificação de aves aquáticas. No entanto, as comunidades de macroinvertebrados variaram sazonalmente e foram influenciadas pelas variáveis ambientais da água. A riqueza e a composição variaram entre as estações e foram influenciadas pelas variáveis físico-químicas e pelos nutrientes da água. A turbidez e o total de sólidos dissolvidos da água influenciaram a riqueza, enquanto que os nutrientes afetaram a abundância de macroinvertebrados. Nossos resultados indicam que a falta de efeito da presença de colônias de nidificação de aves aquáticas na comunidade de macroinvertebrados é possivelmente devido à variação na composição de espécies de aves e ao tamanho reduzido de suas populações, onde em tais casos, quaisquer efeitos das aves sobre os macroinvertebrados podem ser superados pela química da água e pelas mudanças temporais em áreas úmidas intermitentes.

PALAVRAS-CHAVE. Invertebrados aquáticos, banhados, aves aquáticas, química da água.

The aquatic macroinvertebrate community is represented by different taxonomic groups that live all or part of their life cycles in freshwater habitats (MetCaLfe, 1989; BALDWIN et al., 2018). The community structure of aquatic macroinvertebrates is sensitive to many local environmental factors (BATZER et al., 2004; STENERT et al., 2008; Romero et al., 2017; BALDwin et al., 2018). Macroinvertebrate composition in subtropical intermittent wetlands is strongly affected by seasonal changes related either with climate or variation in water availability, as hydroperiod can either constrain the establishment of many taxa or affect water-level environmental conditions
(Stenert \& Maltchik, 2007; Batzer, 2013; Gleason \& RoONEY, 2017). For instance, several studies showed that the richness and composition of aquatic macroinvertebrates is sensitive to changes in water physicochemical variables and nutrient enrichment (BATZER et al., 2004; SigNA et al., 2015). Aquatic macroinvertebrates have therefore been usually used as indicators of the environmental integrity of freshwater ecosystems (CAIRns \& PRATT, 1993; USEPA, 2002; BONADA et al., 2006; EsCRIBANO et al., 2018).

Aquatic macroinvertebrates are key elements of the ecological dynamics of wetlands, linking producers and higher-level consumers such as waterbirds (MeTCALFE, 
1989; BALDWIN et al., 2018). Macroinvertebrates comprise a major part of the food items of waterbirds (MEYER et al., 2015), supplying proteins and other essential nutrients for their survival (ANDERSON \& SMITH, 2000; BALDASSARRE $\&$ Bolen, 2006). It is thus recognized that the occurrence and distribution of macroinvertebrates can affect waterbird habitat selection (KRAPU \& REINECKE, 1992; MEIRE et al., 1994; SAFran et al., 1997; Davis \& SMITH, 1998; PAlOMO et al., 1999; Bolduc \& Afton, 2004; ANDREI et al., 2008; ZMUDCZYŃSKA-SKARBEK et al., 2015). In turn, little is known on the effects of waterbirds on aquatic macroinvertebrates. Previous studies have detected effects of the occurrence of nesting waterbirds and the community structure of macroinvertebrates in ponds (MURKIN \& KADLEC, 1986; WrUBLESKI, 1989; WisZ et al., 2013), although this relationships are not consistent (RoONEY\& BAYLEY, 2012).

Waterbirds can affect macroinvertebrate distribution either through top-down (e.g., via predation), as they have large foraging areas, or bottom-up control mechanisms (e.g., nutrient enrichment) (HaIRSTON et al., 1960; Odum, 1969). The waterbirds deposit nutrients in the form of guano (phosphorus and nitrogen-rich feces) in wetlands, altering the nutrient flow in these ecosystems (ElLIs, 2005; Signa et al., 2012). Studies in European lakes reported that the nutrient enrichment by waterbirds is comparable to the fertilization used in intensive farming (Kolb et al., 2010; SebastianGonZALEZ et al., 2012; GWIAZDA et al., 2014; TELESFORDCHECKLEY et al., 2016).

The high nutrient input (mainly of nitrogen and phosphorus) associated with nesting waterbird colonies (rookeries) (LindeBoOM, 1984; Bosman \& Hockey, 1986; KEATLEY et al., 2009) affects both the water and sediment physicochemical characteristics of the wetlands (KeatLEY et al., 2009; Kolb et al., 2010; Sebastian-GonZalez et al., 2012; GWiazda et al., 2014; Somura et al., 2015; Telesford-Checkley et al., 2016; ChatterJee et al., 2017). These changes in water quality directly influence the primary producers (VALIELA, 1984; ElsER et al., 2007) and, consequently, should potentially impact the macroinvertebrate community, either by increasing or decreasing the abundance of zooplanktonic species (ZeLICKMAN \& GoLOVKINM, 1972), polychaetes (BoSMAN \& HockeY, 1986), crustaceans (PALOMO et al., 1999), chironomids (MichelutTi et al., 2009), and fish (ONUF et al., 1977). In fact, some authors showed that nitrogen enrichment by guano deposition was the driving force of the macroinvertebrate dynamics in coastal lagoons (Signa et al., 2015). Despite the importance of the nutrient enrichment for wetland macroinvertebrates (MARTINEZ, 1993), few studies have assessed the relationships between waterbirds and the macroinvertebrate community through changes related to water nutrient and sediment regime (bottom-up effect) (VitouseK, 1986; Bosman \& HockeY, 1986; Powell et al., 1989; Martinez, 1993).

Beyond the northern hemisphere and particularly in Brazil, much of the current knowledge on the relationships between wetland macroinvertebrates and waterbirds is restricted to descriptions of the food items of waterbirds (SICK, 2001; BELTON, 2004). However, studies investigating the effects of waterbird occurrence on the structure of wetland macroinvertebrate communities and limnological characteristics are missing. The main goal of this study was to assess the taxonomic structure of macroinvertebrate communities in wetlands with and without the presence of nesting waterbirds along two seasonal periods in southern Brazil. The specific objectives were to: 1) to test the effect of the presence of nesting waterbirds on macroinvertebrate richness, abundance and composition; 2) to analyze the relationship of water physicochemical variables, nutrients, sediment (organic matter) with the macroinvertebrate community structure (richness and abundance). Assuming that ponds with and without nesting waterbirds show differences in water and sediment physical and chemical features, and that the macroinvertebrate community varies among different seasonal periods (Prellvitz \& AlBerToni, 2004; Bueno et al., 2003; STENERT et al., 2008; KRAJENBRINK et al., 2019), the following expectations were tested: 1) wetlands with nesting waterbirds have lower macroinvertebrate richness and diversity (ROONEY \& BAYLEY, 2012; GUARESCHI et al., 2015) than wetlands without nesting waterbirds; and 2) the macroinvertebrate composition differs between wetlands with and without nesting waterbirds.

\section{MATERIAL AND METHODS}

Study area. This study was conducted in the municipalities of Estância Velha, Ivoti, Lindolfo Collor, Novo Hamburgo, São Leopoldo and Portão, located in the Porto Alegre Metropolitan Region (PAMR) of the state of Rio Grande do Sul, southernmost Brazil (Fig. 1). The PAMR has an area of $10,300 \mathrm{~km}^{2}$ and is characterized by elevated population density (389.7 inhab $/ \mathrm{km}^{2}$ ) and urbanization rate (over 96\%) (IBGE, 2016). The original vegetation in the study area ranges from Mixed Ombrophilous to Deciduous and Semi-deciduous Seasonal Forests, and the climate is subtropical humid, with temperate climate periods, and the rainfall is well distributed over the year (COMITESINOS, 2015).

Sampling design. Eight wetlands were selected for sampling in this study and classified according to the presence of waterbirds. In four wetlands it was recorded the occurrence of colonies of nesting waterbirds (hereafter 'rookery wetlands'). In the other four wetlands, there were no vestiges of nesting waterbirds (hereafter 'control' wetlands) (Fig. 1). The classification criteria and the bird counting data were retrieved from a simultaneous investigation in the study region that assessed the distribution and feces composition of waterbird species (A. S. Peter, unpubl. data). Over the study period, the following waterbird species were observed in the rookery wetlands: Phimosus infuscatus Poche, 1904, Bubulcus ibis Linnaeus, 1758, Ardea alba Linnaeus, 1758, Egretta thula Molina, 1782, and Nycticorax nycticorax Linnaeus, 1758. The estimated numbers of waterbird individuals in the rookery wetlands over the reproduction period was approximately 600 . However, in one of the wetlands, this number reached $\sim 1,600$ individuals due the high abundance of Phimosus infuscatus dwelling in this pond all year round (A. S. Peter, unpubl. data). 


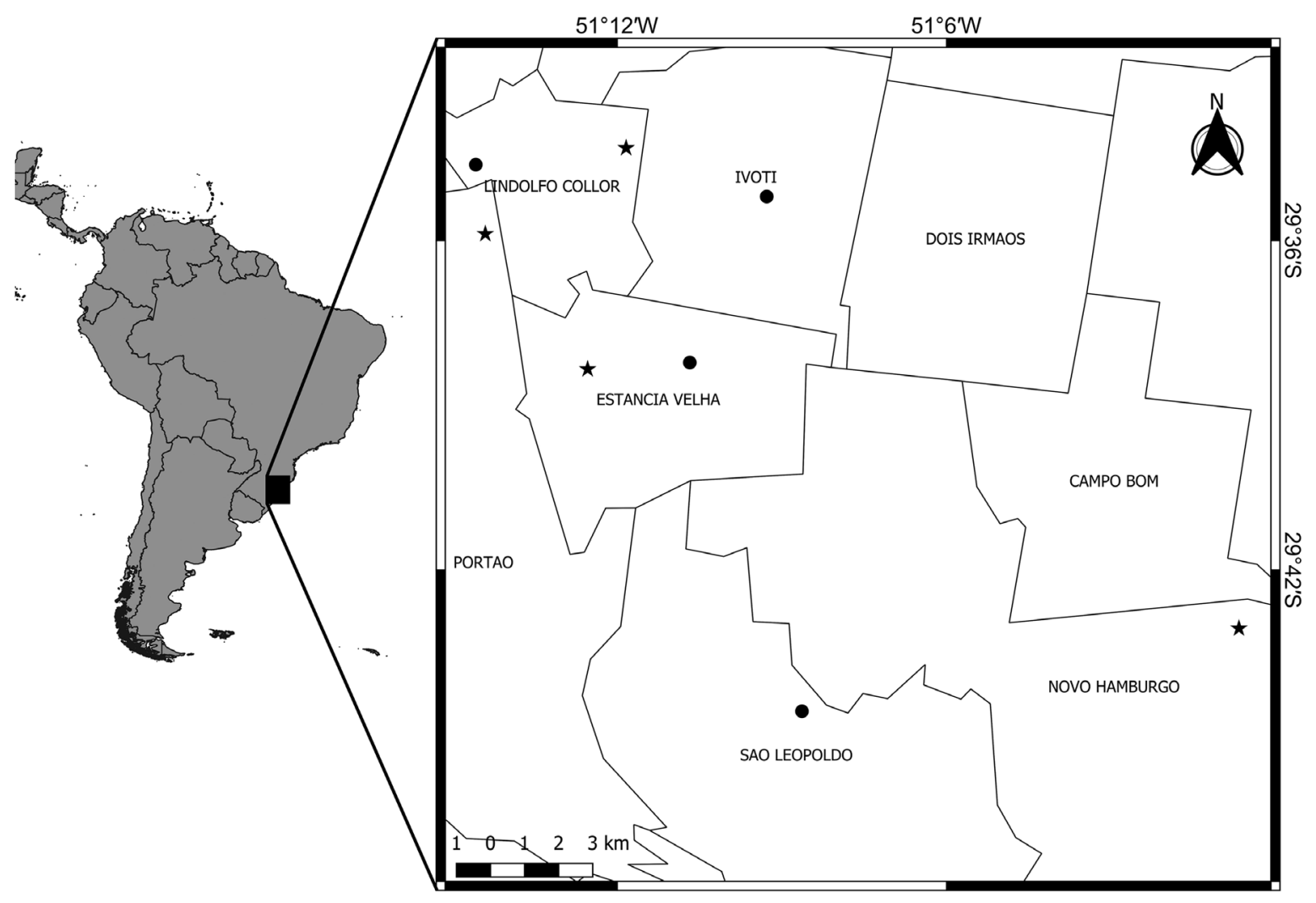

Fig. 1. Map of the study area with the location of the studied wetlands in southern Brazil. Filled circles indicate the control wetlands (wetlands without the presence of nesting bird colonies). Filled stars indicate the rookery wetlands.

All studied wetlands had similar surface flooding areas ( 1 ha), maximum water depth of $50 \mathrm{~cm}$, intermittent hydrological regime, and low anthropic impact. The composition of the surrounding vegetation in the studied wetlands was characterized by arboreal and/or shrubby plants, mainly represented by species such as Mimosa bimucronata (De. Candole) Otto Kuntze, 1891, and Cephalanthus glabratus (Spreng) K. Schum, 1888.

Aquatic macroinvertebrate sampling. Macroinvertebrate sampling was carried out in two seasons: 1) September 2016 (austral spring), the period of the year that corresponds to the beginning of the reproductive period of waterbirds; and 2) May 2017 (austral autumn), corresponding to the waterbird post-reproductive period (Petry \& HoffManN, 2002; Scherer et al., 2006; AcCordi \& BARCELOS, 2006; SCHERER et al., 2011).

On each sampling occasion (spring 2016 and autumn 2017), four subsamples were collected at each wetland with an aquatic frame dip-net (30-cm width; $250-\mu \mathrm{m}$ mesh size) (USEPA, 2002; BALDWIN et al., 2005). Each subsample was represented by three 1-m sweeps, taken after kicking up the substrate and sweeping the disturbed area to capture dislodged or escaping individuals. Posteriorly, the four subsamples were pooled into a single sample and the collected material was fixed in situ with 10\% formaldehyde. In the laboratory, the samples were sieved through a $250-\mu \mathrm{m}$ mesh and the aquatic macroinvertebrate individuals, collected under stereomicroscope and identified to genus level whenever possible (Fernández \& Dominguez, 2001; Merritt et al., 2008). All individuals were preserved in $80 \%$ ethanol and deposited in the aquatic macroinvertebrate collection of the Laboratory of Ecology and Conservation of Aquatic Ecosystems of UNISINOS. Data collection complied with current Brazilian environmental laws (SISBIO 53781-1).

Water and sediment variables. For nutrient content analysis, a 1-L water sample was collected at wetland in the first sampling occasion (September 2016), according to APHA (1998). In the two sampling occasions (autumn and spring seasons), the following water physicochemical variables were measured in situ with a multiparameter probe (HORIBA U-50): water temperature, $\mathrm{pH}$, electrical conductivity, dissolved oxygen, oxygen saturation, total dissolved solids, turbidity and oxidation-reduction potential.

For the analysis of the percentage of organic matter, $\sim 1-\mathrm{kg}$ sediment sample was collected at each wetland in each sampling season for the analysis of the percentage of organic matter. The organic matter was determined after drying sediment at $60^{\circ} \mathrm{C}$ for $24 \mathrm{~h}$ and burning it for $5 \mathrm{~h}$ in an oven at $550^{\circ} \mathrm{C}$ (EMBRAPA, 2006).

Data analysis. Aquatic macroinvertebrate abundance and richness corresponded to the numbers of individuals and taxa collected at each pond, respectively. We used the Simpson's Diversity Index (Simpson's $D=1-\mathrm{D}$ ) to assess the dominance in aquatic macroinvertebrate communities. 
After the detection of non-normal distribution and heteroscedasticity in the diversity data (values of Simpson's D) across treatments, we compared the diversity of aquatic macroinvertebrate communities between rookery and control ponds with a Mann-Whitney test.

We tested the effect of the presence of nesting waterbirds on aquatic macroinvertebrate richness and abundance with generalized linear mixed-effect models (GLMMs). As both response variables were discrete, we fit GLMMs with negative binomial distributions using maximum likelihood estimation (Laplace approximation). The presence of nesting waterbirds was included as fixed factor. In view of the repeated-measurements design and the consequent nonindependence of data originating from the same pond, we investigated for the possible effects of the sampling period by running a set of different models. We ran models including the effect of the seasonal period as a random factor and another as fixed additive factor. We also ran a model including the interaction between the presence of nesting waterbirds and of the seasonal period. We compared the performance of the aforementioned models against null models (intercept only), and we performed model-selection procedures using the Akaike information criterion conditioned for small sample sizes (AICc) (BURNHAM \& ANDERSON, 2002). We retained only the models with $\triangle \mathrm{AIC}<2$ for further inference.

We used stepwise multiple linear regressions with forward selection to investigate the relationships of the environmental variables with the richness and abundance of aquatic macroinvertebrates. We separately investigated the effects of the water physicochemical variables and the effect of nutrients. The analysis of the influence of the environmental variables was undertaken with the full set of seasonal sampling (two sampling periods), and the influence of the nutrients, with the subset of the first sampling period only.

We tested for differences in composition of aquatic macroinvertebrates between rookery and control ponds with a nonparametric multivariate analysis of variance (PERMANOVA) followed by 9999 permutations. We assessed the variation in the composition of aquatic macroinvertebrate communities using nonmetric multidimensional scaling ordination diagram (NMDS). The NMDS and PERMANOVA analyses were based on a dissimilarity matrix (Bray-Curtis index) of the log-transformed abundance data. For the assessment of the influence of the environmental variables on the composition of aquatic macroinvertebrate communities, we fitted the full set of water physicochemical variables and nutrients to the previously generated NMDS ordination diagram of the fauna. All analyses were performed in the statistical environment $\mathrm{R}$ (version 3.5.1)(R DevelOPMENT Core Team, 2018). We fit the GLMMs using the glmer. $n b$ function of the package lme4 version 1.1-15 (BATEs et al., 2015). We respectively run the ordination diagram, the PERMANOVA and the adjustment of the environmental variables with the functions metaMDS, adonis and envfit from package vegan version 2.5-3 (OKSANEN et al., 2018).

\section{RESULTS}

The values of the means and standard deviation of the water physicochemical variables, nutrient content and organic matter of the sediment are listed in Table SI (Supplementary Material). We collected 11,471 individuals from 70 taxa in the studied wetlands. Overall, 4,455 individuals from 50 taxa were collected in the rookery wetlands, and 7,016 individuals from 57 taxa, in the control wetlands. Insecta was the most representative group, corresponding to the majority of the taxa sampled (54 taxa). Coleoptera was the richest insect order, represented by 17 taxa. Chironomidae was the dominant taxon, representing $45 \%$ of all macroinvertebrates collected, followed by Pisidium (Mollusca) and Oligochaeta ( $15.2 \%$ and $13.3 \%$ of the total individuals, respectively). In the rookery wetlands, Chironomidae was the dominant taxon (58.7\% of the individuals), followed by Bezzia sp. $(10.4 \%)$ and Oligochaeta (10\%). In the control wetlands, Chironomidae, Pisidium and Oligochaeta were the dominant taxa $(36.5 \%, 25 \%$ and $15.3 \%$ of the total number of individuals, respectively). In the first sampling season, 9,001 individuals from 60 taxa were collected, while 2,470 individuals from 47 taxa in the second sampling season. The majority of the macroinvertebrate taxa were sampled in both sampling seasons (Tab. I).

Macroinvertebrate communities in rookery wetlands showed higher dominance than control wetlands $(U=10.5$, $g l=1, P=0.001$ ) (Fig. 2). Model selection procedures showed that the presence of nesting waterbirds and sampling seasons did not increase the explanatory power compared to the null model (i.e., models without explanatory variables) for explaining the patterns of macroinvertebrate richness (Tab. II). Macroinvertebrate abundance was not influenced by the presence of nesting waterbirds either, although it varied between sampling seasons. Abundance was higher in the first collection (spring) (Tab. II, Fig. 3).

The output of the stepwise regressions indicated that macroinvertebrate richness was negatively influenced by turbidity and total dissolved solids $\left(R^{2}=0.40, d f=2\right.$, $12, P=0.017)$ (Fig. 4A,B, respectively). Water nutrients did not influence macroinvertebrate richness $\left(R^{2}=0.165\right.$, $d f=4, P=0.32)$. Water physicochemical variables did not influence the macroinvertebrate abundance $\left(R^{2}=0.131\right.$, $d f=8, P=0.47)$. A marginally significant relationship was observed between macroinvertebrate abundance and nitrate and organic phosphorus $\left(R^{2}=0.52, d f=5, P=0.06\right)$ (Fig. $4 \mathrm{C}, \mathrm{D}$, respectively).

The macroinvertebrate composition did not change between rookery and control wetlands (pseudo- $F=1.24, d f=1$, $P=0.28$ ) (Fig. 5A), but differed according to the sampling season (pseudo- $F=2.60, \mathrm{df}=1, P=0.02$ )(Fig. 5B). This effect was clearly displayed by two axes of the NMDS ordination diagram, which showed that some taxa were more associated with the first sampling season (spring), such as Mesovelia Mulsant \& Rey, 1852, Belostoma, Isotoma, Ilybius, Tramea, while Derallus, Lissorhoptrus, Oribatidae, Oxyagrion, Dampfius and Erythemis were more closely associated with the second sampling season (autumn) (Fig. 5B). 
Tab. I. List and number of specimens of aquatic macroinvertebrate taxa recorded in the control and rookery wetlands in each sampling season, southern Brazil.

\begin{tabular}{|c|c|c|c|c|c|}
\hline \multirow[t]{2}{*}{ Taxa } & \multicolumn{2}{|c|}{ Spring } & \multicolumn{2}{|c|}{ Autumn } & \multirow[t]{2}{*}{ Tota } \\
\hline & Control & Rookery & Control & Rookery & \\
\hline
\end{tabular}

BASOMMATOPHORA

Planorbidae

Biomphalaria

105

5

3

Stenophysa

1

SORBEOCONCHA

Ampullaridae

Thiaridae

Pomacea

Hydrobiidae

$$
\text { Heleobia }
$$

Potamopyrgus

VENEROIDA

Sphaeriidae

$$
\text { Pisidium }
$$

OLIGOCHAETA

RHYNCHOBDELLIDA

Glossiphonidae

$$
\begin{gathered}
\text { Haementeria } \\
\text { Helobdella }
\end{gathered}
$$

Tipula

Ephydridae

Hydrellia

Stratiyomidae

$$
\text { Euparyphus }
$$$$
\text { Beris }
$$

Dolichopodidae

Dolichopus

Syrphidae

Eristalis

Sciomyzidae

Sepedon

COLEOPTERA

Dytiscidae

$$
\text { Celina }
$$

Laccophilus

Ilybius
15
120

4


Tab. I. Cont.

\begin{tabular}{|c|c|c|c|c|c|}
\hline \multirow[t]{2}{*}{ Taxa } & \multicolumn{2}{|c|}{ Spring } & \multicolumn{2}{|c|}{ Autumn } & \multirow[t]{2}{*}{ Total } \\
\hline & Control & Rookery & Control & Rookery & \\
\hline \multicolumn{6}{|l|}{ Hydrophilidae } \\
\hline Hidrophilus & 2 & & & & 2 \\
\hline Enochrus & 2 & & 1 & & 3 \\
\hline Berosus & & 1 & & & 1 \\
\hline Laccobius & & 7 & & & 7 \\
\hline Hydrobius & 4 & & 2 & & 6 \\
\hline Hydrobiomorpha & & & & 1 & 1 \\
\hline \multicolumn{6}{|l|}{ Heteroceridae } \\
\hline Derallus & & 7 & & & 7 \\
\hline Dampfius & 1 & & & & 1 \\
\hline \multicolumn{6}{|l|}{ Noteridae } \\
\hline Suphisellus & 1 & & & 1 & 2 \\
\hline Hydrocanthus & 8 & 4 & 1 & & 13 \\
\hline \multicolumn{6}{|l|}{ Notonectidae } \\
\hline Notonecta & 1 & & & & 1 \\
\hline Buenoa & & 2 & & & 2 \\
\hline \multicolumn{6}{|l|}{ Amphizoidae } \\
\hline Amphizoa & & & 2 & & 2 \\
\hline \multicolumn{6}{|l|}{ Curculionidae } \\
\hline Lissorhoptrus & 1 & & & & 1 \\
\hline \multicolumn{6}{|l|}{ HEMIPTERA } \\
\hline \multicolumn{6}{|l|}{ Veliidae } \\
\hline Microvelia & 4 & 1 & 2 & & 7 \\
\hline \multicolumn{6}{|l|}{ Belostomatidae } \\
\hline Belostoma & 7 & 5 & & & 12 \\
\hline \multicolumn{6}{|l|}{ Corixidae } \\
\hline Sigara & & 11 & 1 & & 12 \\
\hline \multicolumn{6}{|l|}{ Naucoridae } \\
\hline Naucoris & & & 1 & & 1 \\
\hline Ambrysus & & 1 & & & 1 \\
\hline \multicolumn{6}{|l|}{ Pleidae } \\
\hline Neoplea & & 2 & & & 2 \\
\hline \multicolumn{6}{|l|}{ Mesoveliidae } \\
\hline Mesovelia & & & & 1 & 1 \\
\hline \multicolumn{6}{|l|}{ Gerridae } \\
\hline Gerris & & & & 2 & 2 \\
\hline \multicolumn{6}{|l|}{ Gelastocoridae } \\
\hline Gelastocoris & & 1 & 1 & & 2 \\
\hline \multicolumn{6}{|l|}{ Homoptera } \\
\hline Delphacidae & & & 6 & 3 & 9 \\
\hline \multicolumn{6}{|l|}{ ODONATA } \\
\hline \multicolumn{6}{|l|}{ Aeshnidae } \\
\hline Aeshna & 2 & 2 & 1 & & 5 \\
\hline Coenagrionidae & & & & & \\
\hline Acanthagrion & 1 & 8 & 4 & 1 & 14 \\
\hline Ischnura & 2 & 1 & 1 & & 4 \\
\hline Oxyagrion & 1 & & & & 1 \\
\hline
\end{tabular}


Tab. I. Cont.

\begin{tabular}{|c|c|c|c|c|c|}
\hline \multirow[t]{2}{*}{ Taxa } & \multicolumn{2}{|c|}{ Spring } & \multicolumn{2}{|c|}{ Autumn } & \multirow[t]{2}{*}{ Total } \\
\hline & Control & Rookery & Control & Rookery & \\
\hline \multicolumn{6}{|l|}{ Libellulidae } \\
\hline Erythrodiplax & 6 & 14 & 9 & 5 & 34 \\
\hline Erythemis & 3 & & & & 3 \\
\hline Micrathyria & 5 & 3 & 7 & & 15 \\
\hline Perithemis & & 1 & & & 1 \\
\hline Orthemis & 1 & 2 & 9 & 6 & 18 \\
\hline Tramea & 2 & & & & 2 \\
\hline \multicolumn{6}{|c|}{ EPHEMEROPTERA } \\
\hline \multicolumn{6}{|l|}{ Baetidae } \\
\hline Callibaetis & 179 & 26 & 4 & & 209 \\
\hline \multicolumn{6}{|l|}{ Caenidae } \\
\hline Caenis & 22 & & 4 & & 26 \\
\hline \multicolumn{6}{|l|}{ Leptophlebiidae } \\
\hline Leptophlebia & & & 1 & & 1 \\
\hline \multicolumn{6}{|l|}{ TRICHOPTERA } \\
\hline \multicolumn{6}{|l|}{ Hydroptilidae } \\
\hline Oxyethira & & 2 & & & 2 \\
\hline Ochrotrichia & 8 & & & & 8 \\
\hline \multicolumn{6}{|l|}{ Rhyacophilidae } \\
\hline Rhyacophila & & & & 1 & 1 \\
\hline \multicolumn{6}{|l|}{ COLLEMBOLA } \\
\hline \multicolumn{6}{|l|}{ Isotomidae } \\
\hline Isotoma $\mathrm{sp}$. & 8 & & & & 8 \\
\hline Isotomurus sp. & 2 & 4 & 3 & 1 & 10 \\
\hline \multicolumn{6}{|l|}{ Poduridae } \\
\hline Podura & 2 & & 4 & 2 & 8 \\
\hline \multicolumn{6}{|l|}{ HYDRACARINA } \\
\hline Oribatidae & 1 & 9 & & & 10 \\
\hline \multicolumn{6}{|l|}{ DECAPODA } \\
\hline \multicolumn{6}{|l|}{ Sesarmidae } \\
\hline Armases & 2 & & 1 & & 3 \\
\hline \multicolumn{6}{|l|}{ ISOPODA } \\
\hline \multicolumn{6}{|l|}{ Aseliidae } \\
\hline Asellus & 135 & & & 1 & 136 \\
\hline Total & 5,382 & 3,619 & 1,634 & 836 & 11,471 \\
\hline
\end{tabular}

The water physicochemical variables significantly correlated with macroinvertebrate composition were water temperature $\left(R^{2}=0.79, P=0.002\right)$, oxidation-reduction potential $\left(R^{2}=0.35, P=0.035\right)$ and water turbidity $\left(R^{2}=\right.$ $0.48, P=0.023)$. The organic matter of sediment was also significantly correlated with macroinvertebrate composition $\left(R^{2}=0.49, P=0.024\right)$ (Fig. 5B). Water temperature and sediment organic matter showed the highest values in the first sampling season (spring), while water turbidity and oxidation-reduction potential showed the highest values in the second sampling season (autumn) (Fig. 5B). In the first sampling season, orthophosphate was the water nutrient variable significantly correlated with macroinvertebrate composition $\left(R^{2}=0.8, P=0.026\right)$ (Fig. 5C). 
Tab. II. Output of the model selection procedures for the effects of the presence of nesting birds and sampling season on the richness and abundance of aquatic macroinvertebrates in southern Brazil. Values in parentheses indicate standard errors. All results are given in the log-scale (df, degrees of freedom).

\begin{tabular}{|c|c|c|c|c|c|c|c|}
\hline \multirow{2}{*}{ Response variable } & \multirow{2}{*}{ Best model } & \multirow{2}{*}{ Intercept } & \multicolumn{2}{|c|}{ Fixed factors } & \multirow{2}{*}{ AIC } & \multirow{2}{*}{ df } & \multirow{2}{*}{ Akaike weigh } \\
\hline & & & Bird presence & Season (spring) & & & \\
\hline Richness & $\sim 1$ & 17.3 & - & - & 0 & 2 & 0.71 \\
\hline Abundance & $\sim$ Bird presence + Season & $6.01(0.32)$ & $5.61(0.37)$ & $7.19(0.75)$ & 0 & 4 & 0.84 \\
\hline
\end{tabular}

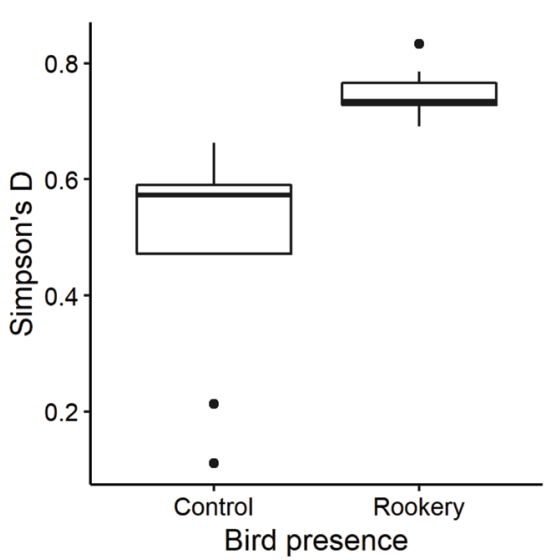

Fig. 2. Simpson's diversity index of the macroinvertebrate communities in control and rookery wetlands in southern Brazil.

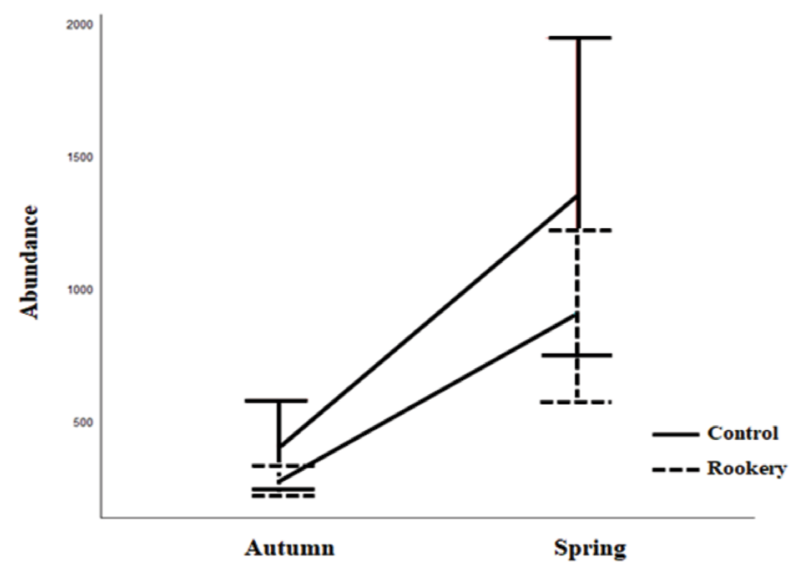

Fig. 3. Abundance of aquatic macroinvertebrates in control and rookery wetlands in each sampling season, southern Brazil. Whiskers indicate upper and lower $95 \%$ confidence intervals ( \pm standard error).

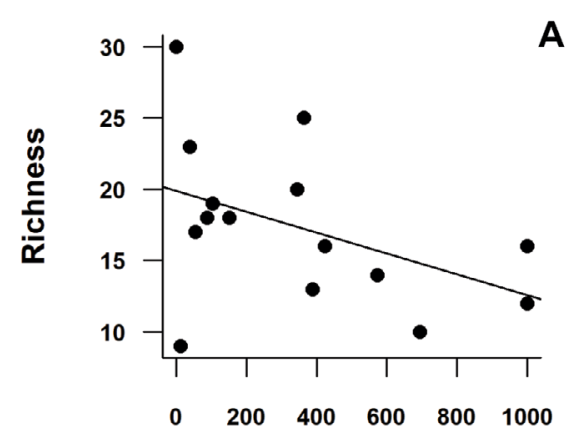

Water turbidity (NTU)

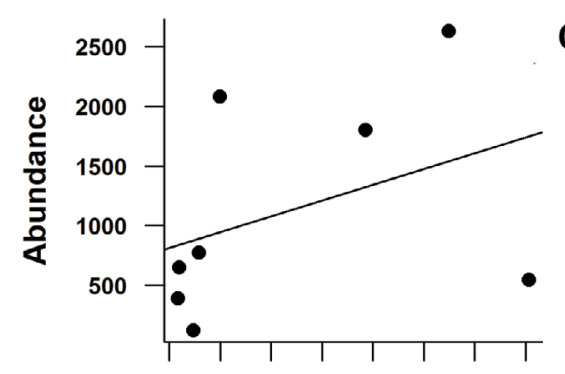

$\begin{array}{llllllll}0 & 1 & 2 & 3 & 4 & 5 & 6 & 7\end{array}$

Nitrate (mg/L)

A

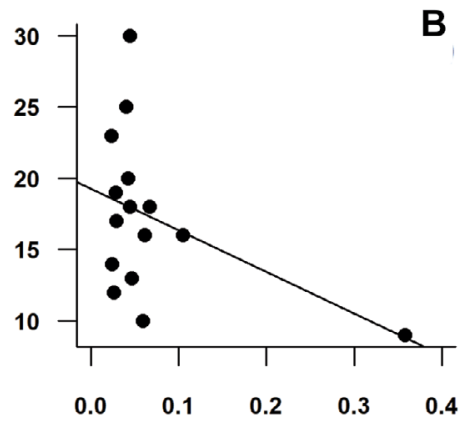

$\operatorname{TDS}(\mathbf{m g} / \mathrm{L})$

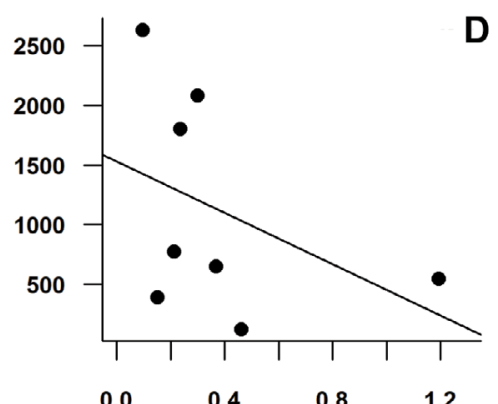

Organic phosphorus (mg/L)

Fig. 4. Relationships between the richness of aquatic macroinvertebrate communities and water turbidity (A), total solids dissolved (B). Relationships between the abundance of aquatic macroinvertebrates and nitrate (C) and organic phosphorus (D)(TDS, total dissolved solids). 

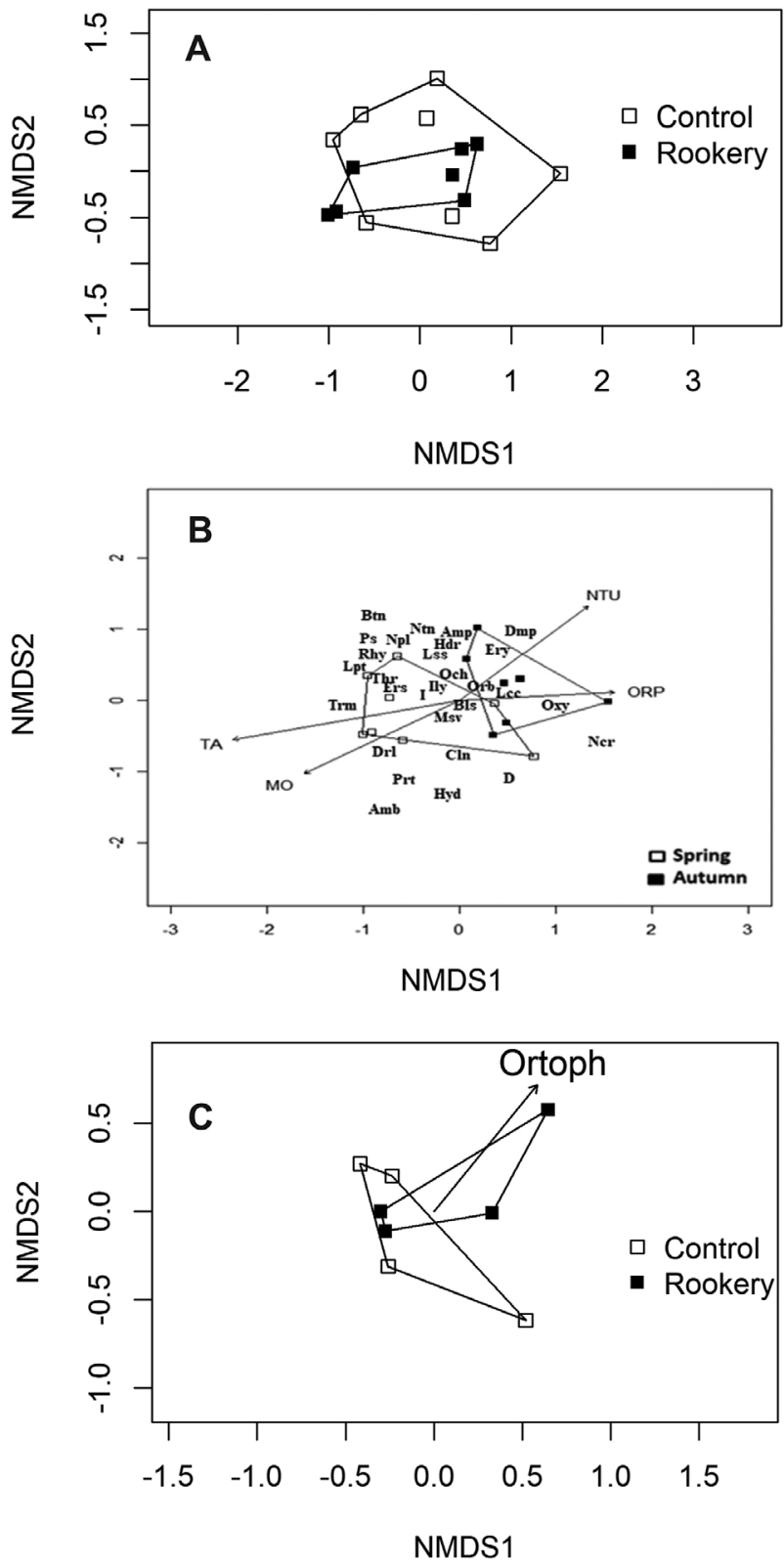

Fig. 5. NMDS ordination diagram of (A) the composition of aquatic macroinvertebrate communities in control and rookery wetlands in southern Brazil; (B) NMDS ordination diagram of the composition of aquatic macroinvertebrate communities and sampling seasons. Red arrows indicate the water physicochemical variables significantly correlated $(\mathrm{P}<$ 0.05 ) with the ordination, as detected by the envfit procedure. Abbreviation of water physicochemical variables: $\mathrm{T}$ (water temperature), $\mathrm{MO}$ (organic matter in the sediment), NTU (water turbidity); ORP (oxidation-reduction potential). Taxa abbreviation: Physa/Stenophysa (P.S), Thiaridae (Thr), Sepedon (Spd), Celina (Cln), Hidrophilus (Hdr), Dampfius (Dmp), Notonecta (Ntn), Lissorhoptrus (Lss), Belostoma (Bls), Oxyagrion (Oxy), Tramea (Trm), Erythemis (Ery), Ochrotrichia (Och), Isotoma sp. (I), Oribatidae (Orb), Leptophlebia (Lpt), Eristalis (Ers), Amphizoa (Amp), Naucoris (Ncr), Delphacidae (D), Rhyacophila (Rhy), Mesovelia (Msv), Gerris (Grr), Ilybius (Ily), Hydrobiomorpha (Hyd), Berosus (Brs), Laccobius (Lcc), Derallus (Drl), Buenoa (Bun), Ambrysus (Amb), Neoplea (Npl), Perithemis (Prt). (C) projection of the water nutrients significantly correlated $(\mathrm{P}<0.05)$ with the ordination of aquatic macroinvertebrate communities in the first sampling season (spring 2016), as detected by the envfit procedure (Ortoph, orthophosphate).

\section{DISCUSSION}

The richness of aquatic macroinvertebrates observed in the studied wetlands was similar to other studies developed in southern Brazilian intermittent wetlands (STENERT \& MaltchiK, 2007; Stenert et al., 2008; MALtchiK et al., 2010; BoELTER et al., 2018). Aquatic insects represented the majority of the wetland invertebrate fauna. The large dominance of insects is related to several life-history traits that allow their survival to temporary habitats (WILLIAMS, 2006). In particular, morphophysiological characteristics of insects such as egg resistance, the presence of wings which facilitate dispersal and the occurrence of terrestrial life stages in many insect species favor their adaptation to the wet-dry periods typical of intermittent wetlands (WILLIAMs, 2006; MerritT et al., 2008). Chironomidae was the most representative group ( $45 \%$ of the total number of individuals collected). Previous studies also observed the dominance of Chironomidae in southern Brazilian wetlands and across several regions of the world (Ávila et al., 2011; SigNa et al., 2015; DAMANiK-Ambarita et al., 2016; Pires et al., 2016; Boelter et al., 2018; ChaWAKa et al., 2018). The high dominance of Chironomidae in wetlands may be associated with their tolerance to adverse conditions, such as low oxygen levels and high organic load (DE HaAs et al., 2006; SignA et al., 2012).

The macroinvertebrate richness, abundance and composition in the studied wetlands did not change according to the presence of colonies of nesting waterbirds. Therefore, the two expectations of the study were not corroborated. This result contrasts with previous studies that detected relationships between the occurrence of nesting waterbirds and macroinvertebrate community structure in wetlands (Murkin \& Kadlec, 1986; Wrubleski, 1989; Wisz et al., 2013; Signa et al., 2015). For instance, GuARESCHI et $a l$. (2015) showed that waterbird presence was negatively correlated to aquatic macroinvertebrate richness, while ROONEY \& BAYLEY (2012) observed a weak correlation between waterbird and invertebrate communities in Canadian ponds. SIGNA et al. (2015) observed that the input of waterbird feces decreased the macroinvertebrate abundance and diversity in Italian pond systems.

The lack of influence of nesting waterbirds on the community structure of aquatic macroinvertebrates could be related to the low number of individuals in the rookery wetlands studied. In the studies that found relationship between macroinvertebrate community structure and waterbird occurrence (MURKIN \& KADLEC, 1986; WRUBLESKI, 1989; Wisz et al., 2013) the abundance of nesting waterbirds ranged between 4,000 and 45,000 individuals, i.e., much higher than the bird populations observed in this study.

Another possible reason for the absence of effect of nesting waterbirds on macroinvertebrate communities is the variation in the reliance on macroinvertebrates for consumption along waterbird life cycles and among species. Specifically, the rate of consumption by waterbirds differs according the phases (i.e., among reproduction, development, 
feather substitution phases, etc.) (ANDREI et al., 2008; ZMUDCZYŃSKA-SKARBEK et al., 2015). In addition, there is large interspecific variation in the diet types and foraging modes among waterbird species (STAFFORD et al., 2016). That is, such differences could lead to varying effects of waterbirds on macroinvertebrates either among species or seasons. In this study, the composition of waterbirds varied among wetlands and could be related to the lack of systematic effect.

Although the community structure of aquatic macroinvertebrates did not change between rookery and control wetlands, the richness and composition were influenced by the water nutrients and physicochemical variables. Richness was negatively influenced by water turbidity and total dissolved solids, and the composition was influenced by water temperature, oxidation-reduction potential, turbidity, sediment organic matter, and orthophosphate. Many studies detected relationships between water physicochemical variables and macroinvertebrate communities in wetlands (ZIMMER et al., 2000; BATZER et al., 2004; STENERT \& MALTCHIK, 2007; STENERT et al., 2008; TOKESHI \& ARAKAKI, 2012; BISCHOF et al., 2013; StRACHAN et al., 2015; BARros et al., 2016; GLEASON \& RoONEY, 2017; ROMERO et al., 2017; BALDWIN et al., 2018). Some authors detected reductions in macroinvertebraterichness with increasing turbidity (BATZER, 2013; JOHNSON et al., 2013; SundBERG et al., 2016; BALDWIN et al., 2018). Elevated turbidity is associated with a higher number of suspended organic and inorganic matter in the water, usually due to the allochthonous material input and the sediment stirring (Gonçalves et al., 2012; Davies-Colley \& SMith, 2001; KARNA et al., 2015), which can significantly impact the aquatic biota (BILOTTA \& BRAZIER, 2008), including the macroinvertebrate community (JoNEs et al., 2012). Organic matter (detritus particles and other kinds of food, such as phytoplankton, periphytic algae, and bacteria) is one of the main food item of wetland macroinvertebrates (BRÖNMARK \& Hansson, 1998). Piedras et al. (2006) observed a positive relationship between densities of Oligochaeta and Chironomidae with sediment organic matter in lentic habitats. In our study, the macroinvertebrate community was dominated by collectors and scrapers, such as Oligochaeta, dipterans, mollusks, and gastropods, i.e. taxa that feed on suspended particles in the water column (MERRITT et al., 2008). This result may explain the effect of sediment organic matter on the macroinvertebrate composition.

Macroinvertebrate abundance and composition varied over the seasons in this study. Seasonal changes in the community structure of aquatic macroinvertebrates in temporary wetlands are described in the literature. STENERT et al. (2008) and KRAJENBRINK et al. (2019) observed seasonal changes in macroinvertebrate richness over the time in ponds. Temporal variations in macroinvertebrate abundance, richness, and composition may be due to the alterations of the water physical and chemical variables observed over the timein lentic habtiats (TUNDISI \& MATSUMURA-TUNDISI, 2008; GLEASON \& RoONEY, 2017; RoMero et al., 2017; BALDWIN et al., 2018; CHAWAKA et al., 2018). Intermittent wetlands alternate wet and dry cycles over time, and the duration of the drought period is considered the major force driving the composition of macroinvertebrates (WELLBORN et al., 1996; WiLliams, 1998, 2006). In addition, seasonal changes in climate can also affect macroinvertebrate composition, as several taxa have their life cycles attached to temperature in subtropical regions (Dallas \& Ross-GillesPIE, 2015).

In summary, our results showed that the nutrients and physicochemical variables in the water and sediment along with seasons influenced the aquatic macroinvertebrate communities in the studied wetlands rather than the occurrence of nesting colonies of waterbirds. Although our study did not detect significant relationships of aquatic macroinvertebrate community structure with the presence of nesting waterbirds (in contrast with the original expectations), this study is, to our knowledge, the first attempt to relate patterns in wetland macroinvertebrate communities and waterbirds in subtropical regions from Brazil. These results are loosely in accordance with the reviews describing unpredictable relationships of wetland macroinvertebrate and their potential predators (BATZER, 2013) and with other findings that suggest that relationships between the waterbirds and their invertebrate prey vary among study regions and are dependent on several contingencies (SANDERS, 2000; Ma et al., 2010; STAFFORD et al., 2016). Nevertheless, the relationships between nutrient enrichment and macroinvertebrate communities detected in the wetlands could have been associated with waterbird presence, suggesting the need for future studies. A deeper understanding of the ecological interactions between these groups is of fundamental importance for wetland ecology and waterbird conservation in southern Brazil, since wetlands in southern South America are important habitats for many resident and migratory waterbird species (CBRO, 2016). Finally, we highlight the need to take into account different sampling periods for the assessment of the effects of nesting colonies on macroinvertebrate communities in southern Brazil (Petry \& Hoffmann, 2002; Petry \& FonseCa, 2005; SCherer et al., 2006, 2011, 2014; Petry \& SCherer, 2008).

Supplementary material. The following online material is available for this article: Mean and standard deviation $( \pm)$ of the physical and chemical variables of water, nutrients and organic matter of the sediment in the control and rookery wetlands.

Acknowledgments. We are grateful to Marlon Ferraz da Rosa for the development of the map of the study area. $\mathrm{DCZ}$ received a $\mathrm{PhD}$ scholarship from Coordenação de Aperfeiçoamento de Pessoal de Nivel Superior (CAPES). LM and CS are continuously supported by the Conselho Nacional de Desenvolvimento Científico e Tecnológico (CNPq) through Research Productivity grants. MMP was granted a postdoctoral fellowship by CNPq (grant number 151152/2018-7) and is currently supported by CNPq at UNISINOS Biology Graduate Program (grant number 159829/2019-4). 


\section{REFERENCES}

ACCORDI, I. A. \& BARCellos, E. A. 2006. Composição da avifauna em oito áreas úmidas da Bacia Hidrográfica do Lago Guaíba, Rio Grande do Sul. Revista Brasileira de Ornitologia14(2):101-115.

ANDERSON, J. T. \& Smith, L. M. 2000. Food selection and feather molt by nonbreeding American green-winged teal in Texas playas. The Journal of Wildlife Management64(1):222-230.

Andrei, A. E.; Smith, L. M.; Haukos, D. A. \& SuRLes, J. G. 2008. Habitat use by migrant shorebirds in saline lakes of the Southern Great Plains. The Journal of Wildlife Management 72(1):246-253.

APHA - American Public Health Association. 1998. Standard Methods for the Examination of Water and Wastewater. Washington (D. C.), APHA/American Water Works Association/Water Pollution Control Federation.

Ávila, A. C. De; Stenert, C. \& Maltchik, L. 2011. Partitioning Macroinvertebrate Diversity Across Different Spatial Scales in Southern Brazil Coastal Wetlands. Wetlands 31(3):459-469.

Baldassarre, G. A. \& Bolen, E. G. 2006. Waterfowl ecology and management. Malabar, Krieger Publishing Company. 580p.

Baldwin, D. S.; Nielsen, D. L.; Bowen, P. M. \& Williams, J. 2005. Recommended Methods for Monitoring Floodplains and Wetlands. Murray-Darling Basin Commission 72(4):1-86.

Baldwin, R. C.; Sundberg, M. D.; Stewart, T. W. \& Weber, M. J. 2018. Influence of Sieve Mesh Size on Relationships between Macroinvertebrate Assemblage and Environmental Variables in Wetlands. Wetlands 38(4):677-687.

Barros, M. P.; Gayeskia, L. M. \& Tundisi, J. G. 2016. Benthic macroinvertebrate community in the Sinos river drainage basin, Rio Grande do Sul, Brazil. Brazilian Journal of Biology 76(4):942-950.

Bates, D.; Maechler, M.; Bolker, B. \& Walker, S. 2015. Fitting Linear Mixed-Effects Models Using lme4. Journal of Statistical Software 67(1):1-48.

Batzer, D. P. 2013. The seemingly intractable ecological responses of invertebrates in North American wetlands: A review. Wetlands 33(1):115.

Batzer, D. P.; PaliK, B. J. \& Buech, R. 2004. Relationships between Environmental Characteristics and Macroinvertebrate Communities in Seasonal Woodland ponds o Minnesota. Journal of the North American Benthological Society 23(1):50-68.

Belton, W. 2004. Aves silvestres do Rio Grande do Sul. Porto Alegre, Fundação Zoobotânica do Rio Grande do Sul. 175p

Bilotta, G. S. \& Brazier, R. E. 2008. Understanding the influence of suspended solids on water quality and aquatic biota. Water Research 42(12):2849-2861

Bischof, M. M.; Hanson, M. A.; Fulton, M. R.; Kolka, R. K.; Sebestyen, S. D. \& BUtLER, M. G. 2013. Invertebrate community patterns in seasonal ponds in Minnesota, USA: Response to hydrologic and environmental variability. Wetlands 33(2):245-256.

Boelter, T.; Stenert, C.; Pires, M. M.; Medeiros, E. S. F. \& Maltchik, L. 2018. Influence of plant habitat types and the presence of fish predators on macroinvertebrate assemblages in southern Brazilian highland wetlands. Fundamental and Applied Limnology 192(1):65-77.

Bolduc, F. \& AFton, A. D. 2004. Relationships between wintering waterbirds and invertebrates, sediments and hydrology of Coastal Mash Ponds. Waterbirds 27(3):333-341.

Bonada, N.; Prat, N.; Resh, V. H. \& Statzner, B. 2006. Developments in aquatic insect biomonitoring: A comparative analysis of recent approaches. Annual Review of Entomology 51(1):495-523.

Bosman, A. L. \& Hockey, P. A. R. 1986. Seabird guano as a determinant of rocky intertidal community structure. Marine Ecology, Progress Series 32(1):247-257.

Brönmark, C. \& Hansson, L. A. 1998. The Biology of Lakes and Ponds. NewYork, Oxford University Press. 323p.

Bueno, A. A. P.; Bond-Buckup, G. \& Ferreira, B. D. P. 2003. Estrutura da comunidade de invertebrados bentônicos em dois cursos d'água do Rio Grande do Sul, Brasil. Revista Brasileira de Zoologia 20(1):115-125.

BurnhAM, K. P. \& ANDERSON, D. R. 2002. Model selection and multimodel inference: a practical information-theoretic approach. New York, Springer. $447 \mathrm{p}$.
Cairns, J. \& Pratt, J. R. 1993. A history of biological monitoring using benthic macroinvertebrates. In: Rosenserg, D. M. \& RESH, V. H. Freshwater biomonitoring and benthic macroinvertebrates. Vol. 4. New York, Chapman \& Hall, p. 10-27.

Chatterjee, A.; Adhikari, S. \& Mukhopadhyay, S. K. 2017. Effects of Waterbird Colonization on Limnochemical Features of a Natural Wetland on Buxa Tiger Reserve, India, During Wintering Period. Wetlands 37(1): 177-190.

Chawaka, S. N.; Boetsa, P.; Goethalsa, P. L. M. \& Mereta, S. T. 2018. Does the protection status of wetlands safeguard diversity of macroinvertebrates and birds in southwestern Ethiopia? Biological Conservation 226(1):63-71.

COMITESINOS. 2015. Projeto Verde Sinos. Avaliable at $<\mathrm{http} / / / \mathrm{www}$. comitesinos.com.br/>. Accessed on 17 August 2015.

CRBO. 2016. Relatório anual de rotas e áreas de concentração de aves migratórias no Brasil. Brasília, Instituto Chico Mendes de Conservação da Biodiversidade. 63p.

Dallas, H. F. \& Ross-Gillespie, V. 2015. Sublethal effects of temperature on freshwater organisms, with special reference to aquatic insects. Water 41(5):712-726.

Damanik-Ambarita, M. N.; Lock, K.; Boets, P.; Everaert, G.; Nguyen, T. H. T.; Forio, M. A. E. \& DomingueZ-Granda, L. 2016. Ecological water quality analysis of the Guayas river basin (Ecuador) based on macroinvertebrates indices. Limnologica-Ecology and Management of Inland Waters 57(1):27-59.

DaVIes-Colley, R. \& Smith, D. G. 2001. Turbidity, suspended sediment, and water clarity: a review. Journal of the American Water Resources Association 37(5):1085-1101.

DAVIS, C. A. \& SMITH, L. M. 1998. Ecology and management of migrant shorebirds in the Playa Lakes Region of Texas. Wildlife Monographs 140(1): $1-45$.

De Haas, E. M.; Wagner, C.; Koelmans, A. A.; Kraak, M. H. S. \& ADMIRAAL, W. 2006. Habitat selection by chironomid larvae: fast growth requires fast food. Journal of Animal Ecology 75(1):148-155.

ELLIS, J. C. 2005. Marine birds on land: A review of plant biomass, species richness, and community composition in seabird colonies. Plant Ecology 181(2):227-241.

Elser, J. J.; Matthew, M. E. S.; Cleland, E. E.; Gruner, D. S.; Stanley Harpole, W.; Hillebrand, H.; Ngai, J. T. ; Seabloom, E. W. ; Shurin, J. B. \& SMITH, J. E. 2007. Global analysis of nitrogen and phosphorus limitation of primary producers in freshwater, marine and terrestrial ecosystems. Ecology Letters 10(12):1135-1142.

EMBRAPA - Empresa Brasileira de Pesquisa Agropecuária. 2006. Sistema Brasileiro de Classificação de Solos. Rio de Janeiro, Centro Nacional de Pesquisa de Solos, Embrapa Solos. 286p.

Escribano, N.; Oscoz, J.; Galicia, D.; Cancellario, T.; Durán, C.; NAVARRO, P. \& ARIÑO, A. 2018. Freshwater macroinvertebrate samples from a water quality monitoring network in the Iberian Peninsula. Scientific Data 5(1):180108.

FERnÁNDEZ, H. R. \& DomíngueZ, E. 2001. Guía para la determinación de los Artrópodos bentónicos sudamericanos. San Miguel de Tucumán, Universidad Nacional de Tucumán. 282p.

GLEason, J. E. \& RoONEY, R. C. 2017. Pond permanence is a key determinant of aquatic macroinvertebrate community structure in wetlands. Freshwater Biology 63(3):264-277.

Gonçalves, J. C. S. I.; Sardinha, D. S.; Souza, A. D. G.; Dibiazi, A. L. B.; Godoy, L. H. \& ConCEIÇÃo, F. T. 2012. Avaliação espaço temporal da qualidade da água e simulação de autodepuração na bacia hidrográfica do córrego São Simão, SP. Ambi-Água 7(3):141-154.

Guareschi, S.; Abellán, P.; Lain, A.; Green, A. J.; SÁncheZ-ZaPata, J. A.; Velasco, J. \& Millán, A. 2015. Cross-taxon congruence in wetlands: Assessing the value of waterbirds as surrogates of macroinvertebrate biodiversity in Mediterranean Ramsar sites. Ecological Indicators 49(1):204-215

Gwiazda, R.; Woznica, A.; LozowsKi, B.; Kostecki, M. \& Flis, A. 2014. Impact of waterbirds on chemical and biological features of water and sediments of a large, shallow dam reservoir. Oceanological and Hydrobiological Studies 43(4):418-426.

Hairston, N. G.; Smith, F. E. \& Slobodkin, L. B. 1960. Community structure, population control, and competition. The American Naturalist 94(879):421-425. 
IBGE - Instituto Brasileiro de Geografia e Estatística. 2016. IBGE Cidades. Avaliable at $<\mathrm{http}$ : //www.ibge.gov.br/cidadesat/topwindow. htm?1>. Accessed on 10 October 2016.

Johnson, P. T. J.; Hoverman, J. T.; Mckenzie, V. J.; Blaustein, A. R. \& RichGels, K. L. D. 2013. Urbanization and wetland communities: applying metacommunity theory to understand the local and landscape effects. Journal of Applied Ecology 50(1):34-42.

Jones, J. I.; Murphy, J. F.; Collins, A. L.; Sear, D. A.; Naden, P. S. \& Armitage, P. D. 2012. The impact of fine sediment on macroinvertebrates. River Research and Applications 28(8):1055-1071.

Karna, N.; Hari Prasad, K. S.; Giri, S. \& Lodhi, A. S. 2015. Effect of fine sediments on river hydraulics a research review. ISH Journal Hydraulic Engineering 21(2):151-161.

Keatley, B. E.; Douglas, M. S. V.; Blais, J. M.; Mallory, M. L. \& Smol, J. P. 2009. Impacts of seabird-derived nutrients on water quality and diatom assemblages from Cape Vera, Devon Island, Canadian High Artic. Hydrobiology 621(1):191-205.

Kоцв, G. S.; Екноцм, J. \& НАмвӓск, Р. А. 2010. Effects of seabird nesting colonies on algae and aquatic invertebrates in coastal Waters. Marine Ecology Progress Series 417(1):287-300.

Krajenbrink, H. K, J.; Acreman, M.; Dunbar, M. J.; Hannah, D. M.; CÉDRIC, L. R. \& Wood, L. P. J. 2019. Macroinvertebrate community responses to river impoundment at multiple spatial scales. Science of the Total Environment 650(1):2648-2656.

Krapu, G. L. \& ReInecke, K. J. 1992. Foraging ecology and nutrition. In: Batt, B. D. J.; Afton, A. D.; Anderson, M. G.; Ankeny, C. D.; Johnson, D. H.; Kadlec, J. A.; \& Krapu, G. L. eds. Ecology and Management of Breeding Waterfowl. Minneapolis, University of Minnesota Press. 29p.

LindeBoom, H. J. 1984. The nitrogen pathway in a penguin rookery. Ecology 65(1):269-277.

MA, Z.; CAI, Y.; LI, B. \& CheN, J. 2010. Managing Wetland Habitats for Waterbirds: An International Perspective. Wetlands 30(1):15-27.

MaltchiK, L.; Rolon, A. S. \& Stenert, C. 2010. Aquatic macrophyte and macroinvertebrate diversity and conservation in wetlands of the Sinos River basin. Brazilian Journal of Biology 70(4):1179-1184.

Martinez, M. M. 1993. Las aves y la limnología. Conferencias de limnología. La Plata, Instituto de Limnología "Dr. R. A. Ringuelet". $145 \mathrm{p}$.

Meire, P. M.; ScheKkerman, H. \& Meininger, P. L. 1994. Consumption of benthic invertebrates by waterbirds in the Oosterschelde estuary, SW Netherlands. Hydrobiologia 282(1):525-546.

Merritt, R. W.; Cummins, K. W. \& Berg, M. B. 2008. An introduction to the aquatic insects of North America. Dubuque, Kendall Hunt Publishing. 1158p.

MetCALFE, J. L. 1989. Biological water quality assessment of running waters based on macroinvertebrate communities: History and present status in Europe. Environmental Pollution 60(1,2):101-139.

MeYer, M. D.; Davis, C. A. \& DvoretT, D. 2015. Response of wetland invertebrate communities to local and landscape factors in north Central Oklahoma. Wetlands 35(3):533-546.

Michelutti, N.; Keatley, B. E.; Brimble, S.; Blais, J. M.; Huijun, L.; Douglas, M. S. V.; Mallory, M. L.; Macdonald, R. W. \& Smol, J. P. 2009. Seabird-driven shifts in Arctic pond ecosystems. Proceedings of the Royal Society 276(1656):591-596.

Murkin, H. R. \& Kadlec, J. A. 1986. Responses by benthic macroinvertebrates to prolonged flooding of marsh habitat. Canadian Journal of Zoology 64(1):65-72.

Odum, E. P. 1969. The strategy of ecosystem development. Science 164:262270.

Oksanen, J.; Blanchet, F. G.; Friendly, M.; Kindt, R.; Legendre, P.; McGlinn, D.; Minchin, P. R.; O’HARA, R. B.; Simpson, G. L.; SOlymos, P.; Henry, M.; Stevens, H.; Szoecs, E. \& Wagner, H. 2018. Package 'vegan':Community Ecology Package. $R$ package version 2.5-3. Available at $<$ https://CRAN.R-project.org/package $=$ veganR package version 2.4-0>. Accessed on 10 November 2018.

OnUf, C. P.; Teal, J. M. \& VALIELA, I. 1977. Interactions of nutrients, plants growth and herbivory in a mangrove ecosystem. Ecology 58(3):514-526.

Palomo, G.; Iribarne, O. \& Martinez, M. M. 1999. The Effect Of Migratory Seabirds Guano On The Soft Bottom Community Of A Sw Atlantic Coastal Lagoon. Bulletin of Marine Science 65(1):119-128.
Petry, M. V. \& FonseCa, V. S. DA S. 2005. Breeding success of the colonist species Bubulcus íbis (Linnaeus, 1758) and four native species. Acta Zoologica 86(3):217-221.

Petry, M. V. \& Hoffmann, G. R. 2002. Ocupação e construção de ninhos em um ninhal misto de garças e maçaricos (Ciconiiformes) no Rio Grande do Sul. Biociências 10(2):55-63.

Petry, M. V. \& Scherer, J. F. M. 2008. Distribuição da avifauna em um gradiente do Rio dos Sinos, São Leopoldo, Rio Grande do Sul, Brasil. Biodiversidade Pampeana 6(2):19-29.

Piedras, S. R. N.; Bager, A.; Moraes, P. R. R.; Isoldi, L. A.; Ferreira, O. G. L. \& HeEmanN, C. 2006. Macroinvertebrados bentônicos como indicadores de qualidade de água na barragem Santa Bárbara, Pelotas, RS, Brasil. Ciência Rural 36(2):494-500.

Pires, M. M.; Kotzian, C. B.; Spies, M. R. \& Baptista, V. dos A. 2016. Comparative assessment of aquatic macroinvertebrate diversity in irrigated rice fields and wetlands through different spatial scales: an additive partitioning approach. Marine and Freshwater Research 67(1):368-379.

Powell, G. V. N.; Kenworthy, J. \& Fourqurean, W. 1989. Experimental evidence for nutrient limitation of seagrass growth in a tropical estuary with restricted circulation. Bulletin of Marine Science 44(6):324-340.

Prellvitz, L. J. \& Albertoni, E. F. 2004. Caracterização temporal da comunidade de macroinvertebrados associada A. salvinia spp. (Salviniaceae) em um arroio da planície costeira de Rio Grande, RS. Acta Biologica Leopoldensia 26(2):213-223.

R Development Core Team. 2018. R: A language and environment for statistical computing. R Foundation for Statistical Computing, Vienna. Available at $<$ https://www.R-project.org/>. Accessed on 10 October 2018.

Romero, K. C.; Río, J. P. Del; Villarreal, K. C.; Anillo, J. C. C.; Zarate, Z. P.; Gutierrez, L. C.; Franco, O. L. \& Valencia, J. W. A. 2017. Lentic water quality characterization using macroinvertebrates as bioindicators: An adapted BMWP index. Ecological Indicators 72(1):53-66.

RoOney, R. C. \& BAYLey, S. E. 2012. Community congruence of plants, invertebrates and birds in natural and constructed shallow open-water wetlands: do we need to monitor multiple assemblages? Ecological Indicators 20(1):42-50.

Safran, R. J.; Isola, C. R.; Colwell, M. A. \& Williams, O. E. 1997. Benthic invertebrates at foraging locations of nine waterbird species in managed wetlands of the northern San Joaquin Valley, California. Wetlands 17(3):407-415.

SANDERS, M. D. 2000. Enhancing food supplies for waders: inconsistent effects of substratum manipulations on aquatic invertebrate biomass. Journal of Applied Ecology 37(1):66-76.

Scherer, J. F. M.; Scherer, A. L.; Petry, M. V. \& Teixeira, E. C. 2006. Estudo da avifauna associada à área úmida situada no Parque Mascarenhas de Moraes, zona urbana de Porto Alegre (RS). Biotemas 19(1): 107-110.

Scherer, A. L.; Petry, M. V. \& Scherer, J. De F. M. 2011. Estrutura e composição da comunidade de aves aquáticas em uma área úmida no sul do Brasil. Revista Brasileira de Ornitologia 19(3):323-331.

Scherer, J. F. M.; Scherer, A. L. \& Petry, M. V. 2014. Vertical nest stratification of four heron species in southern Brazil. Studies on Neotropical Fauna and Environment 49(1):66-74.

Sebastian-GonZalez, E.; NaVArro, J.; Sanchez-Zapata, J. A.; Botella, F. \& Delgado, A. 2012. Water quality and avian inputs as sources of isotopic variability in aquatic macrophytes and macroinvertebrates. Journal of Limnology 71(1):191-199.

SICK, H. 2001. Ornitologia Brasileira. Rio de Janeiro, Nova Fronteira. 912p.

Signa, G.; Mazzola, A. \& VizzinI, S. 2012. Effects of a small seagull colony on trophic status and primary production in a Mediterranean coastal system (Marinello ponds, Italy). Estuarine, Coast and Shelf Sciency 111(1):27-34.

Signa, G.; Mazzola, A.; Costa, V. \& Vizzini, S. 2015. Bottom-Up Control of Macrobenthic Communities in a Guanotrophic Coastal. PLoS One 10(2):0117544

Somura, H.; Mori, Y.; Masunaga, T. \& Takeda, I. 2015. Estimation of nutrient input by a migratory bird, the Tundra Swan (Cygnus columbianus), to winter-flooded paddy fields. Agriculture, Ecosystems \& Environment 199(1):1-9. 
Stafford, J. D.; Janke, A. K.; Webb, E. B. \& Chipps, S. R. 2016. Invertebrates in Managed Waterfowl Marshes. In: BATZER, D. \& BoIx, D. eds. Invertebrates in Freshwater Wetlands: An International Perspective on their Ecology. Basel, Springer International Publishing. 1372p.

Stenert, C. \& Maltchik, L. 2007. Influence of area, altitude and hydroperiod on macroinvertebrates communities in sourthen Brazil wetlands. Marine \& Freshwater Research 58(11):993-1001.

Stenert, C.; Bacca, R. C.; Mostardeiro, C. C. \& Maltchik, L. 2008. Envoronmental predictors of macroinvertebrates communities in coastal wetlands of Southern Brazil. Marine \& Freshwater Research 59(6):540-548.

Strachan, S. R.; Chester, E. T. \& Robson, B. J. 2015. Freshwater invertebrate life history strategies for surviving desiccation. Springer Science Reviews 3(1):57-75.

SundberG, M. D.; Baldwin, R. C.; Stewart, T. W. \& Weber, M. W. 2016. Linkages between land use, invasive fishes, and prairie pothole wetland condition. Wetlands 36(6):1097-1107.

Telesford-Checkley, J. M.; Mora, M. A.; Grant, W. A.; BoellstorfF, D. E. \& Provin, T. L. 2016. Estimating the contribution of nitrogen and phosphorus to waterbodies by colonial nesting waterbirds. Science of the Total Environment 574(1):1335-1344.

TOKeshi, M. \& ARAKaKI, S. 2012. Habitat complexity in aquatic systems: fractals and beyond. Hydrobiologia 685(1):27-47.

Tundisi, J. G. \& Matsumura-Tundisi, T. 2008. Limnologia. São Paulo, Oficina de Textos. 631p.

USEPA - United States Envinronmental Protection Agency. 2002. Methods of evaluating wetland condition: Developing an invertebrate index of biological integrity for wetlands. Office of Water, U. S. Envinronmental Protection Agency, Washington D. C.

VALIELA, I. 1984. Marine ecological processes. New York and Heidelberg, Springer-Verlag. 346p.
VitouseK, P. M. 1986. Biological invasions and ecosystem properties: can species make a difference? In: Ecology of biological invasions of North America and Hawaii. Berlin, Springer-Verlag (Ecological Studies), p. 163-176.

Wellborn, G. A.; Skelly, D. K. \& Werner, E. E. 1996. Mechanisms creating community structure across a freshwater habitat gradient. Annual Review of Ecology and Systematics 27(1):337-363.

WiLliams, D. D. 1998. The role of dormancy in the evolution and structure of temporary water invertebrate communities. Archiv für Hydrobiologie 52(2):109-124.

Williams, D. 2006. The Biology of Temporary Waters. Oxford, Oxford University Press. 315p.

Wisz, M. S.; Pottier, J.; Kissling, W. D.; Pellissier, L.; Lenoir, J.; Damgand, C. F.; Dormann, C. F.; Forchhammer, M. C.; GrYtnes, J.-A.; Guisan, A.; HeikKinen, R. K.; Høye, T. T.; KüHn, I.; Luoto, M.; Maiorano, L.; Nilsson, M.-C.; Normand, S.; ÖCKinger, E.; Schmidt, N. M.; Termansen, M.; Timmermann, A.; Wardle, D. A.; AASTRUP, P. \& SvENNING, J. C. 2013. The role of biotic interactions in shaping distributions and realised assemblages of species: implications for species distribution model-ling. Biological Review 88(1):15-30.

WRUBLESKI, D. A. 1989. The effect of waterfowl feeding on a chi ronomid (Diptera: Chironomidae) community. In: Sharitz, R. R. \& GibBons, J. W. Freshwater Wetlands and Wildlife. Oak Ridge, U. S. Department of Energy, Office of Science and Technological Information, p. 691-696.

Zelickman, E. A. \& Golovkin, A. N. 1972. Composition, structure and productivity of neritic plankton communities near the bird colonies of the northern shores of Novaya Zemlya. Marine Biology 17(3):265-274.

Zimmer, K. D.; Hanson, M. A. \& ButLeR, M. G. 2000. Factors influencing invertebrate communities in prairie wetlands: A multivariate approach. Canadian Journal of Fisheries and Aquatic Sciences 57(1):76-85.

ZmudCZyŃSKa-SkarbeK, K.; BalaZy, P. \& KuKLINSKi, P. 2015. An assessment of seabird influence on Arctic coastal benthic communities. Journal of Marine Systems 144(1):48-56. 